\title{
Inhalation Bioaccessibility of Potentially Toxic Metals in Tobacco Snuff and Related Exposure Risks
}

\author{
Boisa Ndokiari1 ${ }^{*}$, Brown Holly², Odinga Tamuno-Boma ${ }^{3}$, Cookey Julie² \\ ${ }^{1}$ Department of Chemistry, Rivers State University, Port Harcourt, Nigeria \\ ${ }^{2}$ Department of Medical Laboratory Science, Rivers State University, Port Harcourt, Nigeria \\ ${ }^{3}$ Department of Biochemistry, Rivers State University, Port Harcourt, Nigeria \\ Email: *boisa.ndokiari@ust.edu.ng
}

How to cite this paper: Ndokiari, B., Holly, B., Tamuno-Boma, O. and Julie, C. (2021) Inhalation Bioaccessibility of Potentially Toxic Metals in Tobacco Snuff and Related Exposure Risks. Journal of Environmental Protection, 12, 237-248.

https://doi.org/10.4236/jep.2021.124015

Received: October 16, 2020

Accepted: April 6, 2021

Published: April 9, 2021

Copyright $\odot 2021$ by author(s) and Scientific Research Publishing Inc. This work is licensed under the Creative Commons Attribution International License (CC BY 4.0).

http://creativecommons.org/licenses/by/4.0/

\begin{abstract}
This study determined the concentrations and inhalation bioaccessibility of cadmium, chromium, nickel and zinc in some foreign and locally available tobacco snuff and leaves. For the determination of the heavy metals concentration, the samples were ashed and washed with hydrochloric acid according to standard method. The bioaccessibility test employed the Stimulated Epithelial Lung Fluid (SELF). The total concentration of heavy metals in the four samples investigated ranged between $9.7-14.9 \mu \mathrm{g} / \mathrm{g}, 24.1-37.0$ $\mu \mathrm{g} / \mathrm{g}, 41-69 \mu \mathrm{g} / \mathrm{g}$ and $153-183 \mu \mathrm{g} / \mathrm{g}$ for cadmium, chromium, nickel and zinc respectively. The percentage inhalation bioaccessibility fraction of the four samples investigated ranged between $20.8 \%-59.8 \%, 3.3 \%-8.1 \%, 21.7 \%$ - $48.8 \%$ and $7.6 \%-12.5 \%$ for cadmium, chromium, nickel, and zinc respectively. Statistical analyses using SPSS 21, revealed significant differences in the total concentration of heavy metals in the samples investigated except for Zinc. Risk assessment based on daily consumption of $10 \mathrm{~g}$ of the tobacco snuff employing total concentration of the heavy metals suggests that excluding nickel, all other metals investigated indicated daily intake values above WHO permissible levels. However, with the bioaccessible fractions, only cadmium, a known carcinogen indicated levels above WHO limits. From the results of this study, it can be deduced that consumption of tobacco snuff may induce negative health effects such as cancer and its attendant complications, the risk analysis based on bioaccessible concentration suggests lower health risk than analysis based on total heavy metal concentration; hence the assumption that snuff is a safe alternative to tobacco smoking may be erroneous.
\end{abstract}




\section{Keywords}

Tobacco, Leaves, Snuff, Inhalation, Bioaccessibility, Heavy Metals, Stimulated Epithelial Lung Fluid, SELF, Exposure, Risk

\section{Introduction}

Globally, tobacco smoking, inhalation and sniffing have been reported to be the leading cause of many preventable diseases especially those affecting the heart, liver, lungs, many cancers and premature death over the course of the $20^{\text {th }}$ century. C. A. Viegas [1] reported that there are different forms of tobacco in use based on their mode of ingestion: smoke (cigars and pipes) or smokeless tobacco (snuff). In Nigeria, tobacco snuff is the ground form of tobacco leaves, mixed with potash [2] [3] [4] [5].

Amidst the medicinal properties of tobacco which include anthelmintic [6], anti-nociceptive [7], haematological [8], Antibacterial [9] [10] and several negative effects associated with the consumption of tobacco-based products has been highlighted such as Coronary thrombosis [11], Infertility [12] and Cancer [13] [14] [15].

Tobacco has also been useful as pesticides [16] [17]. The plant has characteristics of being able to absorb and accumulate metals from the soil environment [18] [19]. However, Golia et al. [20] reported that the extent of the absorption and accumulation of these metals from the soil depends on the type of soil, the $\mathrm{pH}$, and the chemical composition of the metal.

Snuff is a smokeless tobacco that is made of finely ground or shredded tobacco leaves. It may have different scents and flavors and may be moist or dry [21]. Moist snuff tobacco is placed in the mouth, usually between the cheek and gum or behind the upper or lower lip. Dry snuff tobacco is inhaled through the nose. Snuff tobacco contains nicotine and many harmful, cancer-causing chemicals that have been reported to cause cancers of the mouth, esophagus, pancreas, gum disease, heart disease, stroke, and other health problems.

One of the primary harm of smoking to lungs comes from the smoke itself [22]. Unlike tobacco smoke, snuff is free of tar and harmful gases such as carbon monoxide and nitrogen oxides. Since it cannot be inhaled into the lungs, there is no risk of lung cancer, bronchitis, and emphysema. It is not known whether nicotine or carbon monoxide is the major culprit responsible for cigarette-induced coronary heart disease. If it is carbon monoxide a switch to snuff would reduce the risk substantially. In conclusion, the rapid absorption of nicotine from snuff confirms its potential as an acceptable substitute for smoking. Switching from cigarettes to snuff would substantially reduce the risk of lung cancer, bronchitis, emphysema, and possibly coronary heart disease as well.

However, the presence of heavy metals in snuffs and tobacco leaves can pose a health challenge. Heavy metals are natural components of the earth's crust that 
cannot be degraded or destroyed. To a small extent, they enter our bodies via food, drinking water and air. As trace elements, some heavy metals (e.g. copper, selenium, zinc) are essential to maintain the metabolism of the human body. However, at higher concentrations, they can lead to poisoning. It has been reported that exposure to Cadmium via inhalation leads to pneumonia, pulmonary edema and death [23], also IARC classified Cadmium as a carcinogen to humans. Some workers [24] [25] in their research reported that inhalation, ingestion, dermal absorption are the major routes of entry of chromium into human systemic circulation, and that it is also carcinogenic, causes nasal septum perforation, asthma, bronchitis, pneumonitis, liver disease, skin allergies, dermatitis, dermal necrosis and dermal corrosion. Zinc has been reported to be toxic on exposure to high doses with health effects as apoptosis by acting on several molecular regulators of programmed cell death, including caspases and protein from the Bel and Bax families [26]. Nickel is the major cause for most allergic skin reactions and leads to allergic contact dermatitis which is a positive dermal patch test [27] [28].

Bioaccessibility is the ability of a given dose of a substance to be absorbed into the systemic circulation [29] [30]. It acts on the principle of being a subcategory of absorption and is the fraction of an administered dose of unchanged substance that reaches the systemic circulation, which generally designated simply the quantity or fraction of the ingested dose that is absorbed. The three major routes of exposure of substances into the systemic circulation are ingestion, inhalation and dermal absorption [31] [32].

A formulated synthetic lung fluid (SLF) known as Gambles solution emulates the extracellular environment of the deep lungs and this has been widely used to access inhalable toxicants in human test subjects [33]. Boisa and his colleagues [34] developed a method for the inhalation bioaccessibility test which includes most components that were previously omitted in vitro formulations. They suggested that their formulation closely approximates human respiratory tract fluid. This study will apply inhalation bioaccessibilty model developed by Boisa et al. [34] to evaluate bioavailabilty of $\mathrm{Cd}, \mathrm{Cr}, \mathrm{Ni}$ and $\mathrm{Zn}$ in tobacco snuff and leaves.

\section{Materials and Method}

\subsection{Collection of Samples}

The foreign and local tobacco snuffs and leaf samples were obtained and identified by the technologist at the Botany department of Rivers State University, Port Harcourt.

\subsection{Experimental Procedure}

The procedure of AOAC, 2000 was adopted for the determination of total metal concentration using standard ashing procedure. The method of Boisa et al. [34] was adopted the inhalation bioaccessibility test, and their recently developed in 
vitro stimulated epithelial lung fluid (SELF) was employed for the test.

\subsection{Ashing and Ash Solution}

The tobacco leaves samples were weighed and oven dried to remove moisture for easy disaggregation, the leaves were ground into fine powder. One gram of $\mathrm{Ni}$ geria snuff (NS), Foreign snuff (FS), Nigerian tobacco leaves (NL), and foreign tobacco leaves (FL) were weighed in triplicates into crucibles and put in Muffle furnace at $105^{\circ} \mathrm{C}$ for 2 hours. Five milliliters of Concentrated HCL was added to the resulting ash and diluted with $20 \mathrm{mls}$ of deionized water, and heated in a fume chamber for 10 minutes. The content was allowed to cool, filtered into a volumetric flask and made up to $100 \mathrm{mls}$ with deionized water (AOAC, 2000). The ash fluid was assayed for the total concentration of $\mathrm{Cd}, \mathrm{Cr}, \mathrm{Ni}$ and $\mathrm{Zn}$ using Atomic Absorption Spectrophotometer (A Analyst 200 AA Spectrometer).

\subsection{Preparation of Stimulated Epithelial Lung Fluid (SELF)}

The method of Boisa et al. [34] was adopted: $500 \mathrm{mls}$ of inorganic and organic reagents each were prepared, and combined to form $1000 \mathrm{ml}$ of reagent in a $1 \mathrm{li}$ ter bottle which contained $260 \mathrm{mg}$ bovine serum albumin, $122 \mathrm{mg}$ cysteine, 100 $\mathrm{mg}$ dipalmitoyl choline, $376 \mathrm{mg}$ glycine and $500 \mathrm{mg}$ Mucin. The resulting fluid was mixed thoroughly. HCL $(0.4 \mathrm{ml})$ was added to attain the desired $\mathrm{pH}$ of $7.4 \pm$ 0.2 .

\subsection{Inhalation Bioaccessibility Extraction}

The Stimulated Epithelial Lung Fluid (SELF) was heated to $37^{\circ} \mathrm{C} \pm 2^{\circ} \mathrm{C}$ in a water bath before use. Triplicate set of approximately $0.3 \mathrm{~g}$ of test samples (tobacco leaves and snuff) were accurately weighed into a labeled centrifuge tube to which $20 \mathrm{ml}$ of the prepared SELF was added. The resulting suspensions were rotated for a range of fixed times at a speed of $30 \mathrm{rpm}$ for 96 hours then centrifuged at $3000 \mathrm{rpm}$ for 10 minutes and the clear supernatant was transferred into fresh tubes and submitted for AAS (Perkin Elmer Analyst 200 model) analysis to determine bioaccessible concentrations of $\mathrm{Cd}, \mathrm{Cr}, \mathrm{Ni}$ and $\mathrm{Zn}$.

\subsection{The Percentage Inhalation Bioaccessible Fraction (\%IBAF)}

The percentage inhalation bioaccessible fraction (\%IBAF) was calculated thus:

$$
\% \mathrm{IBAF}=\frac{\text { BIOACCESSIBLE FRACTION }}{\text { TOTAL CONCENTRATION }} \times 100
$$

\subsection{Risk Assessment}

The risk assessment was calculated after Boisa et al. [34]

$$
D I=\left(F_{t b} \times T R \times S_{\text {mass }}\right) \times B W^{-1}
$$

where:

$$
D I=\text { Daily intake }
$$


$F_{t b}=$ Total or \% bioaccessible concentration

$T R=$ Tracheobronchial retention $(0.75)$

$S_{\text {mass }}=$ Inhalation rate $(10 \mathrm{~g})$ day $^{-1}$

$B W=$ Body weight $(60 \mathrm{~kg})$

\subsection{Quality Control}

Reagent blank was included within the inhalation bioaccessibility extraction procedure, to determine reproducibility; all samples were extracted in triplicate. Instrumental detection limit for the element was $0.1 \mu \mathrm{g} / 1$ with the method detection limit, two orders of magnitude greater at approximately $10 \mu \mathrm{g} / \mathrm{l}$. All reported data are based on the average of three replicate.

\subsection{Statistical Data Analysis}

Statistical analyses were performed using SPSS 21 (SPSS Inc., Chicago, IL, USA). $\mathrm{P} \leq 0.05$ was considered significant. Data are presented as Mean \pm standard deviation (SD). Differences in continuous data were compared using one-way analysis of variance (ANOVA: three or more groups) followed by the post-hoc test.

\section{Results and Discussion}

\subsection{Total Heavy Metal Concentration}

The mean total concentration and standard deviation of $\mathrm{Cd}, \mathrm{Cr}, \mathrm{Ni}$, and $\mathrm{Zn}$ in foreign Snuff were $12.6 \pm 1.7 \mu \mathrm{g} / \mathrm{g}, 24.1 \pm 2.6 \mu \mathrm{g} / \mathrm{g}, 69 \pm 9 \mu \mathrm{g} / \mathrm{g}$ and $172 \pm 18 \mu \mathrm{g} / \mathrm{g}$ respectively, in foreign Leaves were $14.9 \pm 0.6 \mu \mathrm{g} / \mathrm{g}, 37.0 \pm 2.5 \mu \mathrm{g} / \mathrm{g}, 56 \pm 4 \mu \mathrm{g} / \mathrm{g}$ and $183 \pm 10 \mu \mathrm{g} / \mathrm{g}$, respectively (Table 1 ). The mean total concentration and

Table 1. Total Heavy mean concentration of research samples.

\begin{tabular}{cccccc}
\hline Sample Code & $\mathbf{n}$ & $\begin{array}{c}\text { Cadmium } \\
(\mu \mathrm{g} / \mathrm{g})\end{array}$ & Chromium $(\mu \mathrm{g} / \mathrm{g})$ & $\begin{array}{c}\text { Nickel } \\
(\mu \mathrm{g} / \mathrm{g})\end{array}$ & Zinc $(\mu \mathrm{g} / \mathrm{g})$ \\
\hline FS & 3 & $12.6 \pm 1.7$ & $24.1 \pm 2.6$ & $69.0 \pm 9.0$ & $172.0 \pm 18.0$ \\
FL & 3 & $14.9 \pm 0.6$ & $37.0 \pm 2.5$ & $56.0 \pm 4.0$ & $138.0 \pm 10.0$ \\
NS & 3 & $9.7 \pm 1.0$ & $33.0 \pm 1.7$ & $41.0 \pm 4.0$ & $153.0 \pm 13.0$ \\
NL & 3 & $10.7 \pm 1.0$ & $37.0 \pm 2.5$ & $41.0 \pm 7.0$ & $167.0 \pm 5.0$ \\
F value & & 11.998 & 20.083 & 13.500 & 2.873 \\
P value & & 0.002 & 0.000 & 0.002 & 0.103 \\
& & Post Hoc & & 0.898 \\
FS vs FL & 0.391 & 0.015 & 0.356 & 0.664 \\
FS vs NS & 0.269 & 0.040 & 0.068 & 0.993 \\
FS vs NL & 0.556 & 0.015 & 0.060 & 0.152 \\
FL vs NS & 0.013 & 0.373 & 0.042 & 0.299 \\
FL vs NL & 0.025 & 1.000 & 0.160 & 1.000 & 0.577 \\
NS vs NL & & 0.767 & 0.373 & & \\
\hline
\end{tabular}

Values are mean \pm standard deviation. FS: Foreign Snuff; FL: Foreign Tobacco Leaves; NS: Nigerian Stuff; NL: Nigerian Tobacco Leaves; n: Sample Size; vs: Versus. 
standard deviation of Cd, Cr, Ni, and Zn in Nigeria Snuff were $9.7 \pm 1.0 \mu \mathrm{g} / \mathrm{g}$, $33.3 \pm 1.7 \mu \mathrm{g} / \mathrm{g}, 41 \pm 4 \mu \mathrm{g} / \mathrm{g}$ and $153 \pm 12 \mu \mathrm{g} / \mathrm{g}$ respectively, in Nigeria leaves, were $10.7 \pm 0.6 \mu \mathrm{g} / \mathrm{g}, 37.0 \pm 2.5 \mu \mathrm{g} / \mathrm{g}, 41 \pm 7 \mu \mathrm{g} / \mathrm{g}$ and $167 \pm 5 \mu \mathrm{g} / \mathrm{g}$ respectively (Table 1). The concentration range of Cd observed in this study is similar those reported for tobacco in USA and Greece [35] [20], but above those previously reported for tobacco in Nigeria, Ghana and Turkey [18] [36] [37] [38] (Table 2). The concentration range of $\mathrm{Cr}$ observed in this study is above those previously reported for tobacco in UK, and Nigeria [37] [39] (Table 2). The concentration range of $\mathrm{Ni}$ observed in this work is above those previously reported for tobacco and its products [20] [30]-[36] but within range reported by Iskander et al. [40] (Table 2). The concentration range reported for $\mathrm{Zn}$ in this work is consistent with the range reported by Adamu et al. [35] for tobacco leaves in United States. Comparing the concentrations, indicate significant difference was observed between foreign leaves, Nigerian snuff, and Nigerian leaves for cadmium concentration, $(p=0.00, F=12.00)$. For Cr significant difference was observed between Foreign snuff, and each of foreign leaves, Nigerian Snuff, and Nigerian leaves $(p=0.00, F=20.08)$. For Ni significant difference was observed between foreign Snuff, and each of Nigerian Snuff, and Nigerian leaves $(p=0.00, F=13.50)$. For Zn significant difference was observed in all research samples was $(p=0.103, \mathrm{~F}=$ 2.873). The concentration variance noticed between the different matrices studied may be due site-specific characteristics of soils on which they were cultivated, their bioaccumulation capacity, and additives included during processing to the snuff.

\subsection{Bioaccessible Concentrations and Percent Bioaccessibility}

Bioaccessible concentrations of $\mathrm{Cd}$ in snuff and leaves ranged between $5.8-7.3$ $\mathrm{ug} / \mathrm{g}$ and 3.1 - $5.6 \mathrm{ug} / \mathrm{g}$, respectively. For $\mathrm{Cr}$ in snuff and leaves ranged between

Table 2. Comparison of this study's total concentrations of with other published data.

\begin{tabular}{|c|c|c|c|c|c|c|}
\hline Sample & Calcium $(\mu \mathrm{g} / \mathrm{g})$ & Chromium ( $\mu \mathrm{g} / \mathrm{g})$ & Nickel $(\mu \mathrm{g} / g)$ & Zinc $(\mu g / g)$ & Author/Year & Country \\
\hline Snuff & $9.7-12.6$ & $24.1-33.3$ & $41-69$ & $153-172$ & This study & Nigeria \\
\hline Leaves & $10.7-14.9$ & $34.5-37.0$ & $41-56$ & $167-183$ & This study & Nigeria \\
\hline Leaves & $8.6-9.5$ & & $2.7-3.6$ & $154-193$ & Adamu et al., 1989 & USA \\
\hline Cigarettes & $9.1-3.7$ & & & $2.1-161.6$ & Golil et al., 2007 & Greece \\
\hline Cigarettes & $0.2-6.1$ & $0.0-5.6$ & $1.8-2.7$ & $0.9-9.2$ & Stephens et al., 2005 & UK \\
\hline Cigarettes & - & & $2.0-400$ & & Iskander et al., 1986 & USA \\
\hline Cigarettes & $0.0-6.8$ & & & & Lugan-Moulin et al., 2006 & $\begin{array}{c}\text { Several } \\
\text { countries }\end{array}$ \\
\hline Snuff & $1.1-1.7$ & & $1.6-2.9$ & & Pappas et al., 2008 & Alaska \\
\hline Snuff & $3.6-3.7$ & $0.2-0.3$ & $0.0-0.5$ & $22.5-25.5$ & Akpoveta et al., 2011 & Nigeria \\
\hline Snuff & $1.7-3.2$ & & $1.0-1.2$ & & Addo et al., 2011 & Ghana \\
\hline Leaves & $0-77$ & & & & Fusun et al., 2013 & Turkey \\
\hline
\end{tabular}


0.8 - $2.7 \mathrm{ug} / \mathrm{g}$ and 2.0 - $14.0 \mathrm{ug} / \mathrm{g}$, respectively. For Ni in snuff and leaves ranged between 13.0 - $15.0 \mathrm{ug} / \mathrm{g}$ and 13.0 - $20.0 \mathrm{ug} / \mathrm{g}$, respectively. For $\mathrm{Zn}$ in snuff and leaves ranged between 13.0 - $19.0 \mathrm{ug} / \mathrm{g}$ and 19.0 - $20.0 \mathrm{ug} / \mathrm{g}$, respectively (Table 3). Significant difference in bioaccessible concentrations exist between the different matrices for $\mathrm{Cd}, \mathrm{Cr}, \mathrm{Ni}$ and $\mathrm{Zn}$ in SELF (Table 3). Cadmium can get into systemic circulation via inhalation [41]. Table 4 shows an order of increasing percentage inhalation bioaccessibility for FS, FL, NS and NL as Cadmium > Nickel $>$ Zinc $>$ Chromium. The \% bioaccessibility range for $\mathrm{Cd}, \mathrm{Cr}, \mathrm{Ni}$ and $\mathrm{Zn}$ were 20.8 - 59.8, 3.3 - 8.1, 21.7 - 48.8 and 7.6 - 12.0, respectively (Table 4).

The high percent inhalation bioaccessibility range observed in this study for $\mathrm{Cd}(20.8 \%-59.8 \%)$ is consistent with the range $(58.7 \%-67.7 \%)$ reported for total suspended particulate matter (TSP) by $\mathrm{Hu}$ et al., (2012) [41]. The low percent inhalation bioacessibility range $(3.3 \%-8.3 \%)$ observed for $\mathrm{Cr}$ in this study is consistent with the range $(8.2 \%-18.2 \%)$ reported by $\mathrm{Hu}$ et al. [41] for TSP. Also the moderate percent inhalation bioaccessibility range observed for $\mathrm{Ni}$ in this study $(21.7 \%-48.8 \%)$ is consistent with the range $(11.2 \%-23.5 \%)$ reported for

Table 3. Mean bioaccessible concentration of research samples.

\begin{tabular}{cccccc}
\hline Sample Code & $\mathbf{n}$ & $\begin{array}{c}\text { Cadmium } \\
(\mu \mathrm{g} / \mathrm{g})\end{array}$ & $\begin{array}{c}\text { Chromium } \\
(\mu \mathrm{g} / \mathrm{g})\end{array}$ & $\begin{array}{c}\text { Nickel } \\
(\mu \mathrm{g} / \mathrm{g})\end{array}$ & Zinc $(\mu \mathrm{g} / \mathrm{g})$ \\
\hline $\mathrm{FS}$ & 3 & $7.3 \pm 0.5$ & $0.8 \pm 0.1$ & $15.0 \pm 1$ & $13.0 \pm 1$ \\
$\mathrm{FL}$ & 3 & $3.1 \pm 0.2$ & $2.0 \pm 0.2$ & $13.0 \pm 1$ & $19.0 \pm 1$ \\
$\mathrm{NS}$ & 3 & $5.8 \pm 0.8$ & $2.7 \pm 0.4$ & $13.0 \pm 1$ & $19.0 \pm 1$ \\
$\mathrm{NL}$ & 3 & $5.6 \pm 0.4$ & $14.0 \pm 0.1$ & $20.0 \pm 1$ & $20.0 \pm 1$ \\
$\mathrm{~F}_{\text {value }}$ & & 33.358 & 27.074 & 32.750 & 30.750 \\
$\mathrm{P}_{\text {value }}$ & & 0.000 & 0.000 & 0.000 & 0.000 \\
& & Post Hoc & & \\
FS vs FL & 0.006 & 0.011 & 0.262 & 0.008 \\
FS vs NS & 0.222 & 0.056 & 0.015 & 0.008 \\
FS vs NL & 0.046 & 0.008 & 0.015 & 0.004 \\
FL vs NS & 0.072 & 0.323 & 1.000 & 1.000 \\
FL vs NL & 0.009 & 0.071 & 0.004 & 0.767 \\
NS vs NL & 0.998 & 0.116 & 0.004 & 0.767 \\
\hline
\end{tabular}

Values are mean \pm standard deviation. FS: Foreign Snuff; FL: Foreign Tobacco Leaves; NS: Nigerian Stuff; NL: Nigerian Tobacco Leaves; n: Samplesize.

Table 4. Percentage inhalation bioaccessibility of research samples.

\begin{tabular}{ccccc}
\hline Sample Code & Cadmium (\%) & Chromium (\%) & Nickel (\%) & Zinc (\%) \\
\hline FS & 57.9 & 3.3 & 21.7 & 7.6 \\
FL & 20.8 & 5.4 & 23.2 & 10.4 \\
NS & 59.8 & 8.1 & 24.4 & 12.5 \\
FL & 52.3 & 3.8 & 48.8 & 12.0 \\
\hline
\end{tabular}

FS: Foreign Snuff; FL: Foreign Tobacco Leaves; NS: Nigerian Stuff; NL: Nigerian Tobacco Leaves. 
total suspended particulate matter (TSP) by $\mathrm{Hu}$ et al. [41]. But the low percent inhalation bioacessibility range $(7.6 \%-12.5 \%)$ observed for $\mathrm{Zn}$ in this study is not consistent with the range $(54.3 \%-75.3 \%)$ reported by Hu et al. [41] for TSP.

\subsection{Risk Assessment}

The daily intake risk assessment analysis based on an intake of $10 \mathrm{~g}$ of snuff per day is shown in Table 5. For Cd, the daily intake dose derived in this study ranged between 1.2 - $1.6 \mu \mathrm{g} / \mathrm{kgbw} /$ day for total concentrations and ranged between $0.7-0.9 \mu \mathrm{g} / \mathrm{kgbw} /$ day for bioaccessible concentration. Both daily intake doses estimated for total and bioaccessible concentrations in this study for Cd are above WHO tolerable daily intake dose ( $0.5 \mu \mathrm{g} / \mathrm{kgbw} /$ day $)$ [42] [43] [44] for food items.

The daily intake dose derived for $\mathrm{Cr}$ in this study ranged between $3.0-4.2$ $\mu \mathrm{g} / \mathrm{kgbw} /$ day for total and $0.1-0.3 \mu \mathrm{g} / \mathrm{kgbw} /$ day for bioaccessible concentrations. The estimated dose range employing total concentrations are above WHO tolerable daily intake dose (2.3 $\mu \mathrm{g} / \mathrm{kgbw} /$ day) [42] [43] [44] for food items. However, the daily intake dose estimated for the bioaccessible concentration was below the WHO tolerable daily intake dose $(2.3 \mu \mathrm{g} / \mathrm{kgbw} /$ day $)$.

For Nickel, the daily intake dose derived in this study ranged between $5.1-8.7$ $\mu \mathrm{g} / \mathrm{kgbw} /$ day for total and $0.2-1.3 \mu \mathrm{g} / \mathrm{kgbw} /$ day for bioaccessible concentrations. Both intake doses estimated for $\mathrm{Ni}$ using total and bioaccessible concentrations of snuff are below WHO tolerable daily intake dose $(23 \mu \mathrm{gkg} / \mathrm{bw} /$ day $)$ [42] [43] [44].

The daily intake doses for zinc derived in this study ranged between 19.1 $21.5 \mu \mathrm{g} / \mathrm{kgbw} /$ day for total and $1.6-2.4 \mu \mathrm{g} / \mathrm{kgbw} /$ day for bioaccessible concentrations. The daily intake dose estimated using total concentration of snuff was above WHO tolerable daily intake dose (11.6 $\mu \mathrm{g} / \mathrm{kgbw} /$ day $)$ for food items. Conversely, the daily intake dose estimated for the bioaccessible concentration was below the WHO tolerable daily intake dose (11.6 $\mu \mathrm{g} / \mathrm{kgbw} /$ day) [42] [43] [44].

Table 5. Risk assessment.

\begin{tabular}{ccccc}
\hline $\begin{array}{c}\text { Sample } \\
\text { Code }\end{array}$ & $\begin{array}{c}\text { Cadmium } \\
(\mu \mathrm{g} / \mathrm{kgBW} / \text { day })\end{array}$ & $\begin{array}{c}\text { Chromium } \\
(\mu \mathrm{g} / \mathrm{kgBW} / \text { day })\end{array}$ & $\begin{array}{c}\text { Nickel } \\
(\mu \mathrm{g} / \mathrm{kgBW} / \text { day })\end{array}$ & $\begin{array}{c}\text { Zinc } \\
(\mu \mathrm{g} / \mathrm{kgBW} / \text { day })\end{array}$ \\
\hline FS Total & 1.6 & 3.0 & 8.7 & 21.5 \\
BAF & 0.9 & 0.1 & 0.2 & 1.6 \\
NS Total & 1.2 & 4.2 & 5.1 & 19.1 \\
BAF & 0.7 & 0.3 & 1.3 & 2.4 \\
WHO & 0.5 & 2.3 & 23 & 11.6 \\
\hline
\end{tabular}

FS Total: Foreign snuff risk assessment based on total heavy metal concentration; NS Total: Nigerian snuff risk assessment based on total heavy metal concentration; BAF: Bioaccessible fraction risk assessment for foreign and Nigerian snuff; WHO: World Health Organization. 


\section{Conclusions}

The idea that consumption of snuff is less likely to cause harm to human prompted this study. The concentrations of Cd and Ni recorded from the tobacco snuff and leave samples in this study are consistent with those previously published for cigarettes. All the potentially toxic metals studied here indicated varying dissolutions in the synthetic lung fluid (SELF), with $\mathrm{Cd}, \mathrm{Cr}, \mathrm{Ni}$, and $\mathrm{Zn}$ indicating inhalation bioaccessibility ranges of $20.8 \%-59.8 \%, 3.3 \%-8.3 \%, 21.7 \%-48.8 \%$ and $7.6 \%-12.5 \%$, respectively.

The total and bioaccessible concentrations of $\mathrm{Cd}, \mathrm{Cr}, \mathrm{Ni}$, and $\mathrm{Zn}$ were employed for the estimation of daily intake doses with an assumption that adult human subjects will snuff about an average of $10 \mathrm{~g} /$ day. With the total content of $\mathrm{Cd}, \mathrm{Cr}$ and $\mathrm{Zn}$ in the snuff adult human subjects are projected to indicate daily intake doses above WHO tolerable daily intake doses. For more conservative estimations using bioaceesible concentrations, only $\mathrm{Cd}$ indicated daily intake dose above that recommended by WHO for food. Based on the data generated from this study, the risk analysis based on bioaccessible concentration suggests lower health risk than analysis based on total heavy metal concentration; hence the assumption that snuff is a safe alternative to tobacco smoking may be erroneous.

\section{Acknowledgements}

The authors wish to acknowledge Julie Cookey for the funds applied to this research work.

\section{Conflicts of Interest}

The authors declare no conflicts of interest regarding the publication of this paper.

\section{References}

[1] Viegas, C.A. (2008) Non Cigarette Forms of Tobacco Use. Journal of Brazil Pneumology, 34, 1069-1073. http://dx.doi.org/10.1590/S1806-37132008001200013

[2] Ren. N. and Timko, M.P (2001) AFLP Analysis of Genetic Polymorphism and Evolutionary Relationships among Cultivated and Wild Nicotiana Species. Genome, 44, 559-571. https://doi.org/10.1139/g01-060

[3] Ureme, S.O., Ibeagha, I.D., Maduka, I.G. and Ibegbulam, O.G. (2017) The Concentrations of Methaemoglobin, Carboxyhaemoglobin and Some Haematological Parameters in Tobacco Snuff Addicts in Igbo of Nigeria. Nigerian Journal of Physiological Science, 22, 27-30. https://doi.org/10.4314/njps.v22i1-2.54890

[4] Mesembe, O., Bisong, S., Ekong, M. and Ekeoma, A (2008) Neurobehavioural Activity in Albino WISTAR Rats in the Open Field Maze following Long Term Tobacco Diet Ingestion. The Internet Journal of Neurology, 10, 345-363.

[5] Ayo-Yusuf, O.A. and Comolly, G.N. (2011) Applying Toxicological Risk Assessment Principles to Constituents of Smokeless Tobacco Products, Implementation for Product Regulation. Journal of Tobacco Control, 20, 53-57. https://doi.org/10.1136/tc.2010.037135

[6] Anita, A., Melin, R. and Mali, G. (2008) A Review on Antihelmic Plants. Natural 
Oridyct, 7, 406-476.

[7] Maxwell, I.E. and Omeh, S.Y. (2010) Anti-Nociceptive Activity of the Methanolic Leaf of Nicotiana tabacum (LINN). Wilolud Journals, 3, 5-10.

[8] Adeniyi, P.A.O. and Ghazal, O.K. (2012) Effects of Tobacco (Nicotiana tabacum) Leave Aqueous Extract on Haematological Parameters in Wistar Rats. Journal of Applied Pharmaceutical Science, 3, 16-21.

[9] Bakht, J.A. and Shafi, M. (2012) Antimicrobial Activity of Nicotiana tobacam Using Different Solvents Extracts. Pakistan Journal of Botany, 44, 569-463.

[10] Zaidel, M.I., Watoo, F.H., Watii, M.H. and Tamizi, Z.A. (2014) Antibacterial Activities of Nicotive and Its Zinc Complex. African Journal of Microbiology Review, 6, 5134-5137.

[11] Barua, R.S. and Ambrose, J.A. (2013) Mechanisms of Coronary Thrombosis in Cigarettes Smoke Exposure. Arteriosclerosis, Thrombosis, and Vascular Biology, 33, 1460-1467. https://doi.org/10.1161/ATVBAHA.112.300154

[12] Gambo, I.M., Galam, N.Z., Adamu, G., Ayaka, L.O., Habeeb, A.A., Bello, M.M., Bello, N., Rabiu, A.M. and Odeh, S.O. (2013) The Effect of Aqueous Leave Extract of Nicotiana tubacum (Tobacco) on Some Reproductive Parameters and $\mathrm{Mi}$ cor-Anatomical Architecture of the Testis in Male Albino Wistar Rats. Journal of Nature Science Recourses, 3, 137-143.

[13] Bray, F.I. and Weiderpass, E. (2010) Lung Cancer Mortality Trends in 36 European Countries: Secular Trends and Birth Cohort Patterns by Sex and Region 1970-2007. International Journal of Cancer, 126, 1454-1466. https://doi.org/10.1002/ijc.24855

[14] Edwards, B.K., Ward, E. and Kohler, B.A. (2010) Annual Report to the Nation on the Status of Cancer, 1975-2006, Featuring Colorectal Cancer Trends and Impact of Interventions (Risk Factors, Screening, and Treatment) to Reduce Future Rates. Cancer, 116, 544-573. https://doi.org/10.1002/cncr.24760

[15] Shin, H.R., Oh, J.K. and Masuyer, E. (2010) Epidemiology of Cholangiocarcinoma: An Update Focusing on Risk Factors. Cancer Science, 101, 579-585. https://doi.org/10.1111/j.1349-7006.2009.01458.x

[16] Abdul-ghany, S., Hena, H. and Ardalan, S. (2011) Insecticidal Effects of Some Aqueous Plant Extracts on the Control of Khapra Trogoderma granarium Evert. International Conference on Chemical, Biological and Environment Sciences, Bangkok, December 2011, 288-292.

[17] Jindaporn, P., Chalermkiat, S., Luelak, L. and Thanaporn A. (2013) Development of Concentrated Emulsion Containing Nicotiana tabadcum Extract for Use as Pesticide. Journal of Applied Pharmaceutical Science, 3, 16-21.

[18] Fusun, O.P., Ruken, E.D. and Emur, H. (2013) Investigation of Heavy Metal Content of Turkish Tobacco Leaves, Cigarette Butt, Ash and Smoke. Environmental Monitoring Assessment, 185, 9471-9479.

https://doi.org/10.1007/s10661-013-3266-4

[19] Nnoran, I. C. (2015) Copper, Iron and Zinc Concentrations of Tobacco Leaves and Ready to Use Snuff Products on Sale in Imo State Southeastern Nigeria. Journal of Applied and Environment Management, 19, 459-467. https://doi.org/10.4314/jasem.v19i3.16

[20] Golia, E.E., Dimirkou, E.A. and Mitsios, E.I.K. (2002) Accumulation of Metals on Tobacco Leaves (Primings) Grown in an Agricultural Area in Relation to Soil. Bulletin of Environmental Contamination and Toxicology, 79, 158-162. https://doi.org/10.1007/s00128-007-9111-0

[21] George, E. and Fribourg, T. (2010) The Old Snuff House of Fribourg and Treyer at 
the Sign of the Rasp and Crown, No. 34 St. James's Haymarket, London, S. W., 1720, 1920. Nabu Press, London.

[22] Philips, C.V. and Heavner, K.K. (2009) Smokeless Tobacco: The Epidemiology and Politics of Harm. Biomarkers, 14, 79-84. https://doi.org/10.1080/13547500902965476

[23] Jullin, B., Wolk, A., Johnansson, J.E., Andersson, S.O., Andren, O. and Akesson, A. (2012) Dietary Cadmium Exposure and Prostate Cancer Incidence: A Population-Based Prospective Cohort Study. British Journal of Cancer, 107, 895-900. https://doi.org/10.1038/bjc.2012.311

[24] Vainio, H., Heseltine, E., Partensky, C. and Wilbourn, J. (1993) Meeting of the IARC Working Group on Beryllium, Cadmium, Mercury and Exposures in the Glass Manufacturing Industry. Scandinavian Journal of Work, Environment \& Health, 19, 360-363. https://doi.org/10.5271/sjweh.1461

[25] Smith, C. J., Livingston, S. D. and Doolittle, D. J. (1997) An International Literature Survey of "IARC Group I Carcinogens" Reported in Mainstream Cigarette Smoke. Food and Chemical Toxicology, 35, 1107-1130. https://doi.org/10.1016/S0278-6915(97)00063-X

[26] Plum, L.M. Rink, L. and Haase, H. (2010) The Essential Toxin: Impact of Zinc on Human Health. International Journal of Environmental Research Public Health, 7, 1342-1365. https://doi.org/10.3390/ijerph7041342

[27] Cavani, A. (2005) Breaking Tolerance to Nickel. Toxicology, 209, 119-121. https://doi.org/10.1016/j.tox.2004.12.021

[28] Environment Agency (2009) Soil Guideline Values for Nickel in Soil. Science Report-SC050021/Nickel SGV. Environment Agency, Bristol.

[29] Parada, J. and Aguilera, J.M. (2007) Food Microstructure Affects the Bioavailability of Several Nutrients. Journal of Food Science, 72, R21-R32.

https://doi.org/10.1111/j.1750-3841.2007.00274.x

[30] Hong, H.X., Perry, G., Sörgel, F., Gedela, S. and Akulapalli, S. (2009) Bioequivalence \& Bioavailability. Journal of Bioequivalence \& Bioavailability, 1, 1-2.

[31] Environment Agency (2009) Human Health Toxicological Assessment of Contaminants in Soil. Science Report-SC050021/SR2. Environment Agency, Bristol.

[32] Charlet, L., Chapron, Y., Faller, P., Kirsch. R., Stone, A.T. and Baveye, P.C. (2012) Neurodegenerative Diseases and Exposure to Environmental Metals $\mathrm{Mn}, \mathrm{Pb}$ and Hg. Coordination Chemistry Reviews, 256, 2147-2163. https://doi.org/10.1016/j.ccr.2012.05.012

[33] Margues, M.C.R., Leobenberg, R. and Almukainzi, M. (2011) Simulated Biologicaldf Fluids with Possible Application in Dissolution Testing. Journal of Dissolution Technology, 18, 15-28. https://doi.org/10.14227/DT180311P15

[34] Boisa, N., Elom, N., Dean, J.R., Deary, M.E., Bird, G. and Entwistle, J.A. (2014) Development and Application of an Inhalation Bioaccessibility Method (IBM) for Lead in the PM10 Size Fraction of Soil. Journal of Environment International, 70, 132-142. https://doi.org/10.1016/j.envint.2014.05.021

[35] Adamu, C.A., Bell, P.F., Mulchi, C.L. and Chaney, R.L. (1989) Residual Metal Levels in Soils and Leaf Accumulations in Tobacco a Decade Following Farmland Application of Municipal Sludge. Environmental Pollution, 56, 113-126.

https://doi.org/10.1016/0269-7491(89)90170-X

[36] Pappas, R.S., Stanfill, S.B., Watson, C.H. and Ashley, D.L. (2008) Analysis of Toxic Metals in Commercial Moist Snuff and Alaskan Iqmik. Journal of Analytical Toxi- 
cology, 32, 281-291. https://doi.org/10.1093/jat/32.4.281

[37] Akpovetta, O.V., Osakwe, A.S., Egharevba, F., Osaro, K.I., Akpoveta, A.V., Osazuwa, E.J., Okoh, E.B., Okwagi, P., Aweatefe, J.K., Odjighere, M. and Weltime, O.M. (2011) A Comparative Evaluation and Toxicity Assessment of Heavy Metals in Commonly Smoked Cigarette Brands and local Tobacco Snuff Purchased and Consumed in Nigeria. Research Journal of Environmental Toxicology, 5, 359-368.

https://dx.doi.org/10.3923/rjet.2011.359.368

[38] Addo, M.A., Duodu, O.G., Affum, H.A., Gbadago, J.K., Darko, E.O. and Coleman, A. (2011) Determination of Minerals Profile in Ghanaians Local Snuffs and an Imported Snuff Using Instrumental Neutron Activation Analysis. British Journal of Pharmacology and Toxicology, 2, 293-301.

[39] Stephens, W.E., Calder, A. and Newton, J. (2005) Source and Health Implications of High Toxic Metal Concentrations in Illicit Tobacco Products. Environmental Science \& Technology, 39, 479-488. https://doi.org/10.1021/es049038s

[40] Iskander, F.Y., Bauer, T.L. and Klein, D.E. (1986) Determination of 28 Elements American Cigarette Tobacco by Neutron-Activation Analysis. Analyst, 111, 107-109. https://doi.org/10.1039/AN9861100107

[41] Hu, X., Zhang, Y., Ding, Z., Wang, T., Lian, H., Sun, Y. and Wu, J. (2012) Bioaccessibility and Health Risk of Arsenic and Heavy Metals (Cd, Co, Cr, Cu, Ni, Pb, Zn and $\mathrm{Mn}$ ) in TSP and PM2. 5 in Nanjing, China. Atmospheric Environment, 57, 146-152. https://doi.org/10.1016/j.atmosenv.2012.04.056

[42] World Health Organization/Food and Agriculture Organization Expert Committee on Food Addictive (1993) Evaluation of Certain Food Addictive and Contaminations 41th Meeting of the Joint FAO/WHO. World Health Organization, Geneva, 837.

[43] World Health Organization (2001) Guidelines for Drinking Water Quality, 2nd Edition, Vol. 1: Recommendations. World Health Organization, Geneva.

[44] World Health Organization (2008) WHO Report on the Global Tobacco Epidemic 2008: The MPOWER Package (PDF). World Health Organization, Geneva 14. 